\title{
Charles Lee Campbell, 1953 to 1999
}

\author{
Turner B. Sutton, Paul D. Peterson, and Clay S. Griffith
}

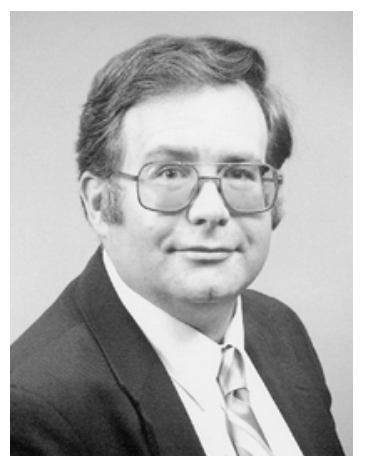

C. Lee Campbell died suddenly on 13 July 1999. He was born on 5 July 1953, the son of Charles and Mary Jane Campbell. He earned both B.S. (1974) and M.S. (1976) degrees in plant pathology at Colorado State University. After receiving his Ph.D. degree from Pennsylvania State University in 1978, Lee became an assistant professor of plant pathology at North Carolina State University in 1979. He was promoted to associate professor in 1985 and to professor in 1991.

Lee's career at North Carolina State University has been widely recognized as a result of his exceptional expertise and dedication to plant pathology combined with a commitment to resolving basic and applied problems related to disease epidemiology, all communicated through his precise, scholarly publications. He also contributed to his chosen discipline through his unyielding devotion to service to The American Phytopathological Society and his involvement in graduate and undergraduate academic programs.

Lee was first and foremost a pioneer leader in the quantitative epidemiology of plant diseases, particularly root diseases. Through his innovative research, including extensive collaborative projects, Lee introduced new and rigorous approaches for ecological studies of soilborne and foliage pathogens and the epidemiology of related diseases. These contributions focused on statistical and predictive models for characterizing pathogen spatial patterns, pathogen dispersal patterns, and a range of factors that affected pattern ontogeny during the development of disease epidemics. He was a pioneer in using electronic data collection and management devices and guided development of software for statistical description and analysis of spatial and temporal patterns of epidemic development. He also documented the effects of environment as well as host genotype and pathogen variation on the shape of disease progress curves and the rate of disease progress. His contributions to the nature of spatial patterns of soilborne pathogens, including nematodes and fungi, provided fundamental information that is employed worldwide to improve population assessment technologies essential to precision agriculture.

Lee collaborated on numerous pathosystems in temperate and tropical systems in North, Central, and South America. He worked with international scientists and students from countries as diverse as Mexico, Panama, the Netherlands, Angola, Nepal, Egypt, Peru, and Scotland.

In 1989, Lee accepted a leadership position in the Agricultural Lands component of the Environmental Monitoring and Assessment Program. This provided an opportunity to extend principles of epidemiology on a regional scale toward development of a paradigm of environmental health. His involvement with this program led to research projects on the effects of global climate change on crop production, use of nematode communities as bioindicators of soil quality, and development and evaluation of numerous other indicators of use in monitoring agroecosystem health in related fields of entomology, landscape ecology, soil science, and agronomy.

Publication no. P-2003-0210-020
Lee was a scholar in the finest sense of the word. He desired to understand and support research in other disciplines that would enrich his own. He had a passionate desire to understand the complex historical forces that shaped plant pathology and continue to influence the science today. His last book, "The Formative Years of Plant Pathology in the United States," underscores the central role that plant pathology played in formative conceptual and institutional developments within biology and the agricultural sciences generally. This book has received glowing reviews from both the scientific and historical communities.

Lee was superb in working with graduate and undergraduate students. This included teaching courses on Botanical Epidemiology, Diseases of Field Crops, and The History of Plant Pathology, as well as serving as an advisor or co-adviser on thesis research projects because of his exceptional expertise in statistics, epidemiology, and related modeling. His insight, knowledge, and even temperament, as well as his highly productive programs, attracted graduate and undergraduate students.

Lee also sought involvement in committees and councils aimed at identifying and shepherding outstanding students. Some $50 \%$ of his time commitment for 1994 to 1997 was devoted to the University Honors Council where he served as its Director. He was a member of the University Scholars Program Advisory Board and the Park Scholarship Committee and was Chair of the Parks Scholars Faculty Advisory Committee for 2 years. He served as President of the local chapters of Sigma Xi and Phi Beta Kappa. For his service to the University he received a Commendation for Meritorious Service and a Media Award for Excellence.

He was dedicated to the service of plant pathology and The American Phytopathological Society. As a graduate student at the Pennsylvania State University, he first became involved in APS as a member of the Phytopathological Classics Committee. Subsequently he served as Secretary-Treasurer, Vice President, and President of the Southern Division of APS and Vice-President, President-Elect, and President of APS from 1997 to 1998, one of the youngest scientists to ever hold that office. Additionally, he was Editor-in-Chief of Phytopathology News from 1990 to 1995 and served on many APS committees.

Lee was a prolific writer and during his short career published 77 referred journal papers on various subjects related to epidemiology. He was the author of 30 chapters in various texts and wrote or edited seven textbooks. Just prior to his death he began revision of his most widely recognized book, "Introduction to Plant Disease Epidemiology," co-authored with Larry Madden.

In recognition of his achievements, Lee was elected a Fellow of the American Association for the Advancement of Science in 1997 and a Fellow of APS in 2000. His scientific achievements and commitment to graduate education are being remembered by a Memorial Lecture Series and a Graduate Student Endowment Fund at North Carolina State University and by an APS Foundation Graduate Student Travel Award.

Lee deeply believed in the value of science based on careful attention to detail and flawless technique, but also informed by well-rounded scholarship. He demanded his science keep an eye to the bigger picture and the duty of service. This attitude made Lee Campbell into the best kind of scientist. Lee is survived by his wife and best friend, Karen. 